Scott S. Reese

\title{
SALAFI TRANSFORMATIONS: ADEN AND THE CHANGING VOICES OF RELIGIOUS REFORM IN THE INTERWAR INDIAN OCEAN
}

\begin{abstract}
The Islamic reformist movement known as Salafism is generally portrayed as a relentlessly literalist and rigid school of religious thought. This article pursues a more nuanced picture of a historical Salafism that is less a movement with a single, linear origin than a dynamic intellectual milieu continually shaped by local contexts. Using 1930s Aden as a case study, the article examines how a transregional reformist discourse could be vulnerable to local interpretation and begins to unpack the transformation of Salafi activism from a broad, doctrinaire, and, above all, foreign ideology to an integral part of local religious discourse. It situates reform within an evolving Islamic discursive tradition that in part developed as a result of its own theological logic but was equally shaped by local and historically contingent institutions, social practices, and power structures. It thus explores Salafism as a dynamic tradition that could be adapted by local intellectuals to engage the problems facing their own communities.
\end{abstract}

On a warm February evening in 1932, Shaykh Muhammad Rashidi, the head of the Ahmadiyya Sufi order in Aden, was relaxing after breaking his fast when two visitors arrived. As it was the holy month of Ramadan there was nothing unusual in this except that, after the exchange of pleasantries, the two men began to question the ' $\bar{a}$ lim aggressively about his beliefs and practices. As they got up to leave, they suggested that the shaykh might want to cease holding Sufi rituals in public or "problems" might arise. ${ }^{1}$ Aggressive Salafi activism had arrived in Aden, but it was not to go unchallenged. Rather than a narrative that relates the strong-arm victory of reformist ideology over local practice, this essay looks at the ways in which promoters of Salafism-conservative scripturalist reform-were ultimately forced to accommodate local institutions and notions of piety in order to become meaningful social actors. The article explores the dynamics of religious mobilization and global reformist discourses in the early 20th-century Indian Ocean, demonstrating how ideologies such as Salafism, while transregional in nature, were in practice shaped by local contexts.

Salafism is the term most commonly used to describe the scripturalist reform movement that arose across the Islamic world from the middle of the 19th century. Proponents

Scott S. Reese is an Associate Professor in the Department of History, Northern Arizona University, Flagstaff, Ariz.; e-mail: scott.reese@nau.edu

(C) Cambridge University Press 2012 0020-7438/12 \$15.00 
of this ideological school called upon Muslims to return to the practices and beliefs of their "pious ancestors" (al-salaf al-sālih) as the only way to purify and revive what they viewed as a flagging faith. The Salafi definition of "the pious ancestors" most often included the Prophet Muhammad and his followers and the immediate two or three generations of Muslims. ${ }^{2}$ Thus, only the earliest scriptural texts (i.e., the Qur'an and the hadith) were accepted as sources of belief and practice. As numerous authors have pointed out, a primary aim of Salafi thinkers was the elimination of the sectarian boundaries that many believed had crippled the community of believers over the centuries and made it vulnerable to European domination. Salafis advocated sweeping away what they viewed as the divisiveness of the four schools of Sunni law and reviving ijtihād to allow believers to directly consult the foundational texts of the faith as guides for their own lives. A return to the foundational sources, as one recent author has noted, would recreate "the utopian era of the salaf," resulting in "greater unity within Muslim communities, political strength and intellectual vitality," and ultimately enabling the umma to throw off the yoke of European domination. ${ }^{3}$ This revitalization, however, also included the eradication of what Salafi proponents regarded as centuries of unlawful innovations ( bid $^{c} a$ ) that included tomb visitation and saint veneration, supplements to established prayer rituals, and local customs deemed out of step with "orthodox" practice. $^{4}$

Salafi ideology in Aden appeared in the early 1920s, and its adherents mirrored the diverse character of the town's wider Muslim community. Proponents ranged from aspiring Arab notables and intellectuals to Indian policemen and civil servants to Somali street hawkers and qat sellers. The movement was bankrolled by the deep pockets of a newly arrived Gujarati merchant and received its intellectual energy from a well-traveled scholar from Ibb, in the Yemeni interior, who had lived and studied extensively in Persia, India, and Afghanistan. The members of this broad, cosmopolitan group typified the rise of transnational Salafism in the early 20th-century Indian Ocean. Their popularity was marked by a number of early victories in the realm of public piety, including the banning of $z \bar{a} r$ (spirit possession rituals) and a curbing of some of the worst excesses (e.g., mixed dancing and public drunkenness) associated with annual festivals centered on the tombs of local saints (ziyārāt).

When activists began to target local Sufis, however, the latter responded with their own tactics of disruption, holding $d h i k r$ in Salafi-controlled mosques and engaging in street scuffles with local pro-Salafi toughs. And it was the reformists who backed down. A series of mediation efforts in 1933 resolved the immediate conflict, and the reciprocal baiting carried out by both sides ceased. The reactions of local Salafi intellectuals and their sympathizers to this apparent defeat were mixed. Some continued to denounce what they viewed as "unlawful innovations," though in a somewhat less militant manner. Others adopted a significantly different approach; rather than the elimination of such abominations, they began to call simply for the "pious" observance of traditions like ziyārāt and dhikr. Through poems, essays, and even short stories dating from the mid1930s, certain Salafi partisans initiated a more literary engagement with the broader Muslim community, seeking to influence rather than eliminate local practices they found abhorrent. Trying to find some sort of common ground, these reformist thinkers began advocating versions of dhikr, ziyārāt, and saint veneration that conformed to their notions of piety. 
Using Aden as a case study, this article examines how a transregional reformist discourse could be vulnerable to local interpretation and begins to unpack the transformation of Salafi activism from a broad, doctrinaire, and, above all, foreign ideology to an integral part of local religious discourse. It situates reform within an evolving Islamic discursive tradition that in part developed as a result of its own theological logic but was equally shaped by local and historically contingent institutions, social practices, and power structures. It thus explores Salafism as a dynamic tradition that could be adapted by local intellectuals to engage the problems facing their own communities.

\section{CHANGING VIEWS OF SALAFISM}

Until recently the dominant trend in scholarship on Islamic reform followed the narrative laid out by Albert Hourani, in which contemporary reformist discourse emerged from the root of a singular "modernism" promoted by Jamal al-Din al-Afghani and Muhammad Abduh, ultimately giving rise to the version of Salafism espoused by Rashid Rida in the 1920s and 1930s. ${ }^{5}$ The accepted narrative held that Salafi ideology sought a return to the "pure" spiritual practices of the "religious and political way of the [pious] forefathers." 6 This renewed path would eschew sectarian divisions and eliminate centuries of "unlawful innovations," represented most visibly by traditions associated with "popular" Sufism, such as saint veneration and tomb visitation. While not disputing this as a particular strain of Salafi thought, more recent scholarship has begun to complicate the picture.

Oliver Scharbrodt, for instance, has demonstrated the heretofore underestimated importance of Sufi thought in the early work of Muhammad Abduh. ${ }^{7}$ David Commins and Itzchak Weismann have established the existence of a significant group of early Salafis, centered around 'Abd al-Qadir al-Jaza'iri in Damascus in the 1880s, who were reluctant to condemn mystical beliefs. ${ }^{8}$ The anti-Sufi trend in Salafi thought, Weismann argues, is a reflection of the dominance of Rida in the 1920s and 1930s and his belief that "latterday tradition, both scholarly and mystic . . . was the cause of the decline of Muslim civilization and ... an impediment to the adoption of useful Western innovations." 9

For the purposes of this article, probably the single most important recent work on Salafi reform is Samira Haj's Reconfiguring Islamic Tradition, which examines the writings of the Egyptian scholar Muhammad Abduh (1849-1905), widely regarded as one of the founders of modern Salafism. Haj's study approaches Abduh's reformist thought as part of a dynamic tradition that drew upon a "corpus of Islamic knowledge" in order to respond to contemporary challenges. This corpus included not just written texts but also intellectual positions, institutions, and social roles. Drawing on works by Talal Asad and Alasdair MacIntyre on the nature and dynamics of "tradition," Haj writes that "tradition is not simply the recapitulation of previous beliefs and practices. Instead, each successive generation" uses it to "confront its particular problems via an engagement with a set of ongoing arguments [or problems]"10 in a process that results in almost constant reinvention. She argues persuasively that, far from being anachronistic, the Salafism of Muhammad Abduh and others was a dynamic framework of inquiry that sought to continually reinterpret Islam in light of changing circumstances while remaining faithful to the spirit of the faith's teachings. The significance of such recent 
work by Haj and others is that Salafism begins to appear less as a movement with a single, linear origin and more as a dynamic intellectual milieu that evolved from a number of centers starting in the late 19th century. It was always shaped by a unique combination of local contexts as well as by the vast repertoire of Islamic tradition. ${ }^{11}$

While this new scholarship engaging reformist discourse within the broad context of the 19th and 20th centuries is important, most of it has tended to focus on the dissemination of ideas through print culture and only at the highest levels of debate. ${ }^{12}$ Far less attention has been paid to the reception of these ideas within particular communities through the medium of local print. ${ }^{13}$ Unsurprisingly, a great chasm frequently separates ideologies in the abstract from their application at the local level amidst the concrete realities of day-to-day living. ${ }^{14}$

\section{PUBLIC PIETY AND THE CULT OF THE SAINTS}

There were probably few locations in the British Empire where as many Muslim intellectual and social trajectories intersected as in Aden (Singapore and Zanzibar being two others). When troops of the East India Company occupied the port in 1839, it was home to a modest population of no more than 1,200 residents. By the 1849 census it had grown to more than 12,000 , by the 1870 s to 19,000 , and by the 1930 s to nearly $50,000 .{ }^{15}$ The overwhelming majority of these residents were Muslim. ${ }^{16}$ It was one of the most ethnically and doctrinally heterogeneous Muslim communities in the empire, including Arabs, Indians, and Somalis who might be Sunni, Shi'i, or Isma 'ili. Over the course of the 19th and early 20th centuries, religious ideals and institutions increasingly formed the center of social and communal life for most Adeni Muslims, which probably comes as little surprise given such a diverse community with little in common other than a more or less shared faith.

Sufism, along with what is often referred to as the "cult of the saints,"17 dominated the public sphere of Aden from before the British occupation through the early decades of the 20 th century. When the British assault commenced in 1839, the majority of the town's population took refuge in the one significant functioning mosque, which housed the tomb of Aden's patron saint Sayyid Abu Bakr al- 'Aydarus (d. 1506). It was the shrine's mutawalli, or caretaker, Sayyid Zayn al-'Aydarus, who negotiated the town's surrender. The tomb was also the location of the town's only major ziyāra (local pilgrimage or festival), an event that attracted not only the majority of townsmen but also thousands of tribesmen from the interior each year. ${ }^{18}$

As the town grew through the remainder of the 19th century, saint veneration and Sufism continued to be the primary expressions of popular spirituality and communal solidarity. By the 1920s Aden boasted more than a dozen annual saints' festivals centered on tombs dotted throughout the settlement. Some of these were associated with particular Sufi orders or turuq, while others were maintained by local followers with only loose affiliations to any particular path. Although festivals were organized by either the various Sufi orders or adherents of a particular saint, they were frequently financed by large associations of merchants, landlords, and other prominent citizens. These individuals gained the admiration of the community for their charity and made a great deal of money from the thousands of pilgrims who came to venerate and honor the deceased. ${ }^{19}$ 
The British administration considered local festivals significant enough to provide minor subsidies to the more important of these civic events each year and occasionally even to participate in them, thus conveying de facto official government sanction on them. Through the 1930s, the Office of the Resident provided grants ranging from ten to fifty rupees for unspecified expenses associated with several of the most popular festivals, while government offices were routinely closed in neighborhoods where ceremonies were taking place (the official reasoning was that the crush of crowds in neighborhoods surrounding the shrines made government work impossible). ${ }^{20}$ On a number of occasions in the 1930s, the British Resident, Bernard Reilly, became an active participant by joining processions to lay the new kiswa, a shroud or covering, over the tomb at several of the more important pilgrimages. ${ }^{21}$

The festivals generally attracted a large cross-section of Aden's Muslim community. A few, such as the ziyārāt of Shaykh Rihan and Shaykh Ishaq, had fairly narrow constituencies (local fisherman and Somali residents, respectively), but most were events with broad popularity. The ziyāra of Sayyid Abu Bakr al-'Aydarus was the city's most important local annual religious event. In addition to involving most of the town's inhabitants, the festival attracted hundreds of people from the near and distant Yemeni interior as well as large numbers of pilgrims from the nearby Somali and Eritrean coasts of East Africa. However, other saints were the focus of broad-based veneration. The ziyāra of Shaykh Abban, whose tomb was administered by Indian Memon Muslims, was organized and financed by some of the settlement's leading Arab families. Similarly, adherents of Shaykh Ahmad al-'Iraqi frequently referred to his tomb using the South Asian Persianate word dargah rather than the more usual Arabic qabr, suggesting a serious Indian following. ${ }^{22}$

The ceremonies surrounding ziyārāt included special prayers, recitations from the Qur'an, and stories detailing the pious deeds of the venerated, and they culminated in a formal procession to the tomb for the installation of the new kiswa. In addition to these religious observances, most festivals maintained a carnival-like atmosphere with numerous diversions for the pious, ranging from the innocent to the risqué. At a typical ziyāra of the 1920s one would find entertainments such as rides, puppet shows, street magicians, and games of skill and chance such as ring toss, the lucky dip, and the odd shooting gallery. In addition to these wholesome amusements, one could pay to dance with girls of the Khadim class wearing "semi-transparent clothes ... and making indecent gestures"; watch Sufis perform "majdhib" (from the Arabic jadhaba, meaning entranced), in which practitioners would cut themselves with daggers while twirling in a trance; or search out illicit alcohol or some serious gambling. ${ }^{23}$ For many these activities constituted just another day at the fair. It should come as little surprise, however, that they attracted the ire of Aden's religious and social reformers.

THE ARAB ISLAMIC REFORM CLUB AND THE ARBITRATION

OF PUBLIC MORALITY

Religious reformers began to challenge the dominance of the popular spiritual status quo in the early 1920s, when a group led by the qadi of Aden, Dawud al-Battah, initiated a campaign against the performance of $z \bar{a} r$ within the settlement limits. A spirit possession cult led by Ethiopian and Somali women and patronized by Arab and Indian women of 
the middle class, $z \bar{a} r$ was present in the settlement from before the time of the British occupation. Whether motivated by incipient Salafi reformist influence or by a sudden growth in the cult's popularity, Qadi Dawud initiated a petition in December 1923 seeking to have it banned. ${ }^{24}$ The qadi and his fellow petitioners argued that the custom should be proscribed not only because it was haram but also, and more important, because the practitioners were preying on women of "rank and honor," duping them out of their savings and "introducing bad moral behavior into the entire community." 25 Backed by the signatures of most of Aden's "respectable citizens" as well as fatwas from three notable religious officials, including the representative of the imam in Sana'a, the Residency and the superintendent of police acted quickly to outlaw the practice. ${ }^{26}$

The anti-zār movement led by al-Battah, though seemingly tinged with Salafi ideas, did not coalesce into a formal association calling for broad social and religious reform. Qadi Dawud's interest in reform seems to have taken him in a different direction; he was instrumental in creating and running the local Waqf Committee, which aimed to eliminate graft and corruption from the administration of the port's pious endowments, and he played little role in later events. The campaign against $z \bar{a} r$, however, brought a number of individuals into the public spotlight who would continue attempting to clean up what they viewed as Aden's immoral streets. They became the founders of Nadi al-Islah al- ${ }^{-}$Arabi al-Islami (Arab Islamic Reform Club). ${ }^{27}$

Nadi al-Islah was established in 1928 or 1929 by a diverse group of individuals from various stations in Aden society who were involved in the anti-zār campaign and whose stated common goal was to undertake "reforms in society." 28 The group was financed by Zakariya Muhammad al-Hindi, a Gujarati merchant and long-time resident of Aden, and Sayyid 'Ali Isma'il, a self-made man originally from the Hadramaut who owned a large slaughtering business in the settlement. ${ }^{29}$ The intellectual impetus for the group was provided by two younger men with largely secular educations, Muhammad 'Ali Luqman and Ahmad Muhammad al-Asnaj. Luqman was the eldest son of the settlement's chief interpreter and had been educated first in the Residency school and then at a school run by priests of the Society of Mary. ${ }^{30}$ Al-Asnaj's father was an entrepreneur of humble origins who by the 1920s dominated much of the local fish trade and who, like his son, was prominent in the anti-zār movement. ${ }^{31}$

The Salafi orientation of Nadi al-Islah and its leadership was present from the club's inception. Muhammad 'Ali Luqman noted in his autobiography that he was inspired to establish the club by 'Abd al-'Aziz al-Tha'alibi, the Tunisian founder of the Destour Party and a Salafi proponent, whom he met in Aden while al-Tha'alibi was on his way to India. ${ }^{32}$ Al-Tha'alibi, Luqman recounted, was astonished by the lethargy of the Muslims of Aden and encouraged him to establish an association or club to promote self-improvement. ${ }^{33}$ Initially, the club served as a kind of salon where members gathered to read Arabic-language newspapers from Egypt and Lebanon, discuss current events, and listen to inspirational political and religious lectures. ${ }^{34}$ At the same time, they engaged in charity work by raising money for Libyan refugees in Egypt and assisting with quarantine efforts during a smallpox outbreak in $1929 .{ }^{35}$ In 1930 the members decided to open a school to provide religious instruction to their own children as well as any other Muslim child who wanted to attend. To run the school, the club recruited an 'älim from nearby Lahej, Shaykh Ahmad b. Muhammad b. Awad al'Abbadi. 
According to his biographer Muhammad b. Salim al-Bayhani, Shaykh al- ${ }^{\circ}$ Abbadi was a highly trained 'älim and a dedicated Salafi who did not shrink from controversy in order to defend his beliefs. Al- 'Abbadi had family ties to the Hadramaut but was born and raised near the town of Ibb around $1882 .{ }^{36}$ In the manner of traditional scholars he studied the Qur'an and the religious sciences under his father. At age seventeen he decided to leave home "in order to seek knowledge and study religion." ${ }^{37}$ He traveled first to Afghanistan, where he studied tafsìr, fiqh, and other sciences under Muhammad Taqi al-Din al-Afghani until around 1908. He then moved to Bombay and studied in the al-Qasab (or al-Qasba) mosque for a year and half. ${ }^{38}$

Following this decade of semi-itinerant study, al- ${ }^{\circ}$ Abbadi settled into a life of teaching and of Salafi activism, first in Oman and then briefly in Ibb. ${ }^{39}$ The shaykh's commitment to activism rather than strictly quietist scholarship is revealed by the choices he made after completing his Central and South Asian sojourn. Upon leaving Bombay, al-'Abbadi settled in the Omani port of Sur, where he secured a position as the imam of a Sunni mosque. According to al-Bayhani, he spent most of his twelve years there engaged in literary skirmishing with the scholars of the Ibadi community, seeking to convince them of the error of their ways. While on the haj near the end of World War I, he received word of his father's death and decided that it was time to return to Yemen. His time in Ibb, however, was brief, as he quickly became involved in a number of unspecified theological disputes with the local Zaydi 'ulama' that were vociferous if not outright violent. ${ }^{40}$ Whether his departure was linked to these disputes is not known, but in 1920 the Sultan of Lahej, 'Abd al-Karim Fadl, asked him to take over a charitable school. ${ }^{41}$ It was from there that Nadi al-Islah invited him, in 1930, to open a school in the Shaykh Uthman suburb of Aden. ${ }^{42}$

Al-'Abbadi's arrival in Aden was significant because it coincided with the club's movement from a literary and occasional social-service organization toward a mission that emphasized proselytizing and activism. It is impossible to determine, based on the available evidence, whether or not al- 'Abbadi's arrival was directly responsible for Nadi al-Islah's more visible public profile in the early 1930s, but the evidence is suggestive. ${ }^{43}$

\section{SALAFIS ON THE OFFENSIVE}

As Henri Lauzière has argued in a recent article, the term Salafism did not begin to come into wide usage until the 1920s. As it did so the label was accompanied by a great deal of ambiguity, encompassing individuals from a broad spectrum of thought ranging from scriptural literalists to "modernists," all of whom looked to al-salaf al-sālih as role models. ${ }^{44}$ The leadership of Nadi al-Islah reflected this trend. Al-'Abbadi and alBayhani were scripturally oriented scholars who believed Muslims needed to rigorously cleanse the faith of erroneous doctrinal beliefs and practices (unlawful innovations) in order to return Islam to the purity of its earliest generations. ${ }^{45}$ Luqman and al-Asnaj, as we shall see, were focused less on doctrinal purity than on individual intent and personal action. ${ }^{46}$ All, however, were concerned with the moral fiber of the community, and it was this central concern that held them together under the auspices of the club. ${ }^{47}$

In the spring of 1931 Nadi al-Islah began to take a broad interest in the public spiritual sphere. A number of mosques throughout the city were controlled by members of the club or by individuals sympathetic to them. In Shaykh Uthman (a large outlying 
suburb), Zakariya Muhammad al-Hindi, with backing from his father-in-law, founded what became known as the Masjid Zakoo (the Zakariya Mosque) in 1929 and installed al-'Abbadi as imam. During the same period, Sayyid 'Ali Isma'il successfully took control of the Masjid Ahl al-Khair, formerly known as the Qadi's Mosque, in the same neighborhood. And the main mosque in Tawahi allowed club members to deliver the Friday khutba, or sermon, on a number of occasions. ${ }^{48}$

In these mosques, according to British Residency and police records, reformistinspired sermons became a regular feature of Friday noon prayers. In May and June 1931, prominent club members including Muhammad 'Ali Luqman and Ahmad alAsnaj delivered sermons in the neighborhoods of Shaykh Uthman and Tawahi that were typical of reformist rhetoric. One address delivered on 8 May chided the community for tolerating "drunkenness, sodomy, adultery, and scandal" in their midst and upbraided them for "scoffing at the religion of [their] Prophet" and casting aside the precepts of religious law. Calling on them to "forsake habits of laziness and carelessness," it urged the believers of Aden to reawaken society through "the exercise of piety which is the main guide to good deeds and protection from sin." 49

While the orations at Friday prayers sought to inspire greater moral behavior via words, pro-Salafi activists in the club took more direct action in order to root out sin and irreligious behavior. Sayyid 'Ali Isma'il and others began to circulate petitions calling on the Residency to crack down on immoral behavior, most notably, drinking, gambling, and mixed dancing, at the local ziyārāt. ${ }^{50}$ At the same time, Sayyid 'Ali and Zakariya al-Hindi prohibited the performance of $d h i k r$ in the mosques they controlled and banned a long-standing custom in Aden's mosques, the recitation of certain verses from the Qur'an following the call to prayer and before the start of communal prayers, arguing that these were un-Islamic and dangerous innovations. ${ }^{51}$

Resistance against the reformist campaign was swift. Supporters of one of the most important festivals, that of Sayyid Hashim al-Bahr, quickly sent their own letter to the Residency denouncing the club's actions and arguing that the activities surrounding the ziyāra represented a financial boon to the community. They claimed that more than 20,000 people attended the festival of Sayyid Hashim annually and that each one spent a minimum of five rupees. Money earned at the festival, they argued, enabled many of the poorest of Aden to make it through the year, and any curtailing of activities would cause untold hardship. ${ }^{52}$

In other cases, reactions were not simply quick but aggressive, as demonstrated by the response to club members' attempts to end dhikr in the early months of 1932. Several nights after Salafi adherents paid their visit to Shaykh Rashidi, on 24 February, a large contingent of his Sufi followers gathered for the night prayer at the Salaficontrolled Zakoo Mosque around nine in the evening. Upon completion of their prayers the group stood and began to rock back and forth rhythmically, reciting "Allāhhayy," the beginning of a dhikr. Horrified, the mosque's caretaker jumped up and tried to stop the swaying men, telling them that the mosque's mansab, Zakariya Muhammad, had forbidden such things. According to one report, several of the Sufis produced staves from beneath their robes and duly informed the caretaker that they would finish their prayers. The caretaker went around dousing all of the lights, hoping to break up the meeting; not needing light to worship God, the mystics continued their remembrance. ${ }^{53}$ 
In a similar show of resolve several months later, local worshippers displayed their disdain for Salafi attempts to modify another local ritual, the recitation of a verse from the sūrat al-ahzāa immediately following the call to prayer. ${ }^{54}$ Shaykh al- ${ }^{\mathrm{c}}$ Abbadi, Zakariya al-Hindi, and others had banned this practice from mosques under their influence, which produced a number of confrontational responses. Among the most belligerent was an incident in the Ahl al-Khair mosque in January 1933. The presiding imam had just begun the evening prayer when another group of worshippers arrived on the mosque's verandah and began to start the prayer anew. A near riot erupted between the rival parties and violence was only averted by the efforts of a quick-thinking plainclothed policeman who defused the situation. When asked why he had sought to restart the prayer, the leader of the late arrivals stated that since the verse from the $a h z \bar{a} b$ was not recited following the adhan (the call to prayer), prayer could not possibly have started yet. ${ }^{55}$

The seriousness of these incidents had steadily escalated from the beginning of 1932, and by January 1933 the British authorities were determined to put an end to the matter. Those identified as responsible for the disturbances on both sides were brought before the Resident. Zakariya al-Hindi, Muhammad 'Ali Luqman, Ahmad al-Asnaj, and Shaykh al'Abbadi, from Nadi al-Islah, and the qadis Awad and 'Abdullah Sharaf, proponents of the opposition, were warned that if the groups did not manage to resolve their differences then the government would intervene. Jail and deportation from the settlement were suggested as possible consequences for the parties identified as leaders. ${ }^{56}$ As a result, both sides engaged in a serious attempt at mediation in mid-January 1933, and the incidents ceased.

\section{THE FLUIDITY OF REFORM}

The mediation efforts seemingly brought an end to the physical confrontations and mutual baiting of the previous two years. One reason for this may have been an increased police presence in the streets during periods when tensions might be heightened. ${ }^{57}$ At the same time, those who were identified by the administration as the most visible reformist voices either disappeared from public view or shifted from proselytizing in person to the written word.

After the 1933 mediation, Zakariya al-Hindi and Sayyid 'Ali Isma'il make no further appearances in either the British archival record or local Arabic-language sources. Four other important reformist figures-Ahmad al-'Abbadi, his student and disciple Muhammad al-Bayhani, Ahmad al-Asnaj, and Muhammad 'Ali Luqman —all continued to espouse a reformist agenda but through the use of the printing press rather than the pulpit. Over the course of the 1930s these individuals published important works that at least implicitly addressed the notion of religious reform and correct practice. Shaykh al- ${ }^{-}$Abbadi composed a collection of Salafi religious verse edited and published by his disciple Muhammad al-Bayhani as Hidayat al-Murid ila Sabil al-Haqq wa-Tawhid. ${ }^{58}$ Ahmad al-Asnaj published Nasib 'Adan, a series of essays aimed primarily at "the youth" of Aden. And Muhammad 'Ali Luqman produced what is widely regarded as the first serious work of fiction by a modern Adeni author, the novella $\mathrm{Sa}$ id. While each of these works addressed the issue of religious reform at least indirectly, even the most doctrinaire (al-'Abbadi's poetry collection) represented a significant shift not only in 
terms of how the message was delivered but also in terms of how the author defined the parameters of reform.

\section{Al- 'Abbadi and Hidayat al-Murid}

As a "response to the charlatans and their following,"59 Ahmad al- Abbadi composed a set of poems in the simple and accessible rajaz meter, which were meant not only to smite "the willful oppressors" but also to "spread good among the Muslims." These were collected by the shaykh's protégé Muhammad al-Bayhani and published by alMatba' a al-Salafiyya wa-Maktabatuha in Cairo around 1938, while he was a student at al-Azhar. ${ }^{60}$ Al-Bayhani contributed a biographical introduction of the poems' author as well as critical commentary included in footnotes. ${ }^{61}$ A close reading reveals the Hidayat al-Murid to be a strict interpretation of the faith dedicated to stemming the tide of bid $^{\text {' }}$ a or unlawful innovation and ending "reprehensible customs" among the believers of Aden. ${ }^{62}$ The collection is replete with scathing attacks on practices such as dhikr and ziyārāt as well as condemnations of various local customs. But both the composer and his editor attempted to tread a careful line, seeking to condemn certain practices without alienating the Muslims of Aden.

The poems in Hidayat al-Murid address various broad topics with clear and simple titles such as "On the Boundary between Learning and Ignorance," "On Doctrine," "On Faith," "On Idolatry and Its Types," "On the Tariqa and the Shari'a," and "The Verdict on Tomb Visitation." Both the poems and al-Bayhani's voluminous footnotes contain much that one would expect from a strict Salafi text. Al- 'Abbadi's views on many aspects of Sufism and on tomb visitation are prominent and in accordance with what could be regarded as the mainstream theological Salafism of his day. In his poem "On the Tariqa and the Shari 'a," the shaykh condemns most mystical practices and beliefs as theater at best and debauchery at worst. Dhikr, as practiced locally, was clearly at variance with religious law, an occasion for depravity rather than remembering God:

And what is proper in the shari ${ }^{c} a \ldots$

Is what God sent through His Prophet

As for dancing, "listening" [ $\left.\operatorname{sam}^{\prime} a\right]$, then wailing

And the revelry and yelling of trance

It is as if they are drunk without drinking

[drunk] with dancing and "listening" but not with remembrance

They resemble the branch of the willow tree

They sink to the ground in a state of passion

They claim to be impassioned for God

But the heart is unaware or absent. ${ }^{63}$

The visiting of tombs comes in for equally harsh criticism. In "On Idolatry," al- 'Abbadi declares that

Whomever calls upon the dead or unseen

And looks to it with reverence and desire

In repelling harm or attaining benefit

That is unbelief among the people of the shari ${ }^{c} a{ }^{64}$ 
And in "The Verdict on Tomb Visitation," the faithful are warned unreservedly,

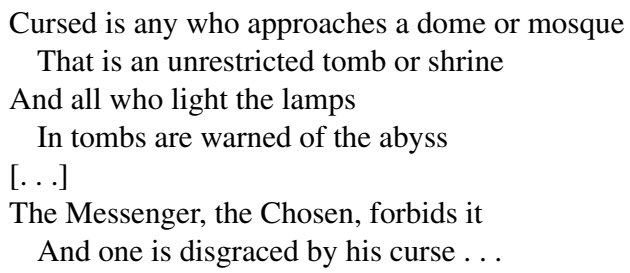

Finally,

\author{
No Muslim can visit a tomb \\ Without committing some vile, forbidden act. ${ }^{65}$
}

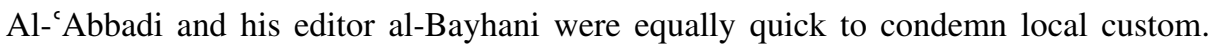
In detailed footnotes al-Bayhani provides the reader with a number of examples of unlawful behavior common among the believers. Some were customs that had evolved from the already suspicious activities surrounding tomb visitation, while others were simply heretical practices akin to sorcery. "A person goes to the local tombs," al-Bayhani writes,
\end{abstract}

And makes a vow to his master that he be favored with a child, male or female ... even though such a request is impermissible to any other than God. And they say " $y \bar{a}$ shaykh fulän ${ }^{66}$ with your favor and station with God, I petition you ..." and when the child reaches seven years of age he goes with his father, the idolater, to the grave of the one to whom the pledge was made and shaves a circle in his head, deeming his hair to be a very good thing, and buries it next to the tomb. $\mathrm{He}$ then butchers a ram just to be sure. If it is a girl child he makes half a payment to the pious shaykh at the time of her marriage to support the performance of festivals and the lighting of his tomb. There is no power of strength save in God! $!^{67}$

Al-Bayhani relates that, among other heinous practices that tempt the believer,

Even among us in Shaykh Uthman there is a woman who goes by the kunya Um 'Aqil [Mother of Reason] upon whom they break eggs and present to her other kinds of sacrifices, and she stops dead many of the brethren, and they fear her gaze. God gives them their reward! And there are many horrible things like this. ${ }^{68}$

The remedy to these ills was, in part, the elimination of customs that were viewed as un-Islamic and a stricter adherence to the law as the authors interpreted it. At the same time, the approach of al- ${ }^{-}$Abbadi and al-Bayhani was not without its accommodations. For instance, while many of the poems condemn various practices, others are concerned with elements of belief that were far less controversial. Several of the earliest poems deal with topics such as "doctrine," "faith," and "the boundary between learning and ignorance," all of which focus on positions with which few believers could disagree. The poem "Between Learning and Ignorance" is concerned almost solely with the idea of the oneness and indivisibility of God. ${ }^{69}$ In one of several poems dealing with tawhìd 
or the "unity of God," al-'Abbadi condemns those who are guilty of unbelief, but the statements are so vague that they point to no one in particular. For example,

Whoever says that he believes firmly in the forbidden

That it benefits you [to know] that he commits unbelief with his message

The people of idolatry, oppose them

They are the worshippers of the forbidden, do not believe them.

They follow a path other than the Truth

Because of that they become wicked beings. ${ }^{70}$

Those who are "wicked" are often left largely unidentified as simply "certain shaykhs." In cases where specific examples of heterodoxy are given, the actual perpetrators are not only vague but also far removed from the precincts of Aden. In "Idolatry and Its Types," al-'Abbadi decries the common practice of seeking the intercession of the saints:

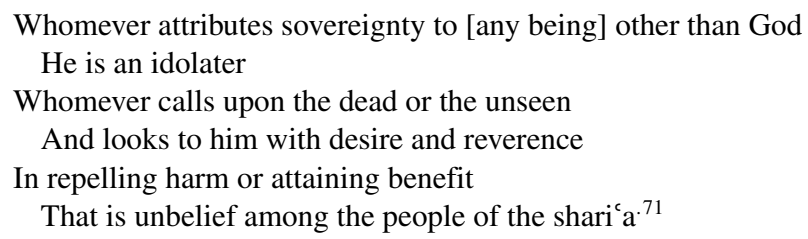

This is certainly a strong statement condemning the idea of saintly intercession or tawassul with God on behalf of the believer. However, it is a statement with which few mystics would disagree, since common Sufi beliefs of the period taught that the awliy $\vec{a}$ perform miracles only through God and not as a result of their own powers. As if recognizing this as a widely held belief of Sufis in Aden, the poem is accompanied with a footnote by al-Bayhani reassuring the reader that while such "odious and malicious" beliefs exist, he had never heard them in Aden. Rather, "I heard such in 1351 [1932] in Djibouti when a person in a mosque said 'Wallăhi! The saints can cause harm and good without God,' God protect us from such words!"72

Certainly, al-'Abbadi and al-Bayhani were dedicated reformers who saw it as their duty to bring the beliefs and customs of their brethren into line with "proper" Salafi teachings. Following the controversies of the early 1930s, however, both demonstrated a desire to effect change without direct confrontation or at least while limiting it as much as possible. Thus al-'Abbadi's collection sought to create a certain amount of common ground by highlighting elements of belief that all could agree upon. When criticism was unavoidable it was kept relatively general and often outright vague. Exemplars of poor behavior tended to be women, foreigners, or, most generically, "those people"individuals who could safely be identified as suspect.

\section{Luqman and al-Asnaj}

In an effort to gain greater influence over the spiritual topography of Aden, al- 'Abbadi and al-Bayhani appeared to tailor not the scripturalist reform message so much as their presentation of it. Two other prominent members of Nadi al-Islah, however, took a very 
different approach toward reform, focusing less on ritual and the finer points of theology and more on notions of individual moral conduct.

Muhammad 'Ali Luqman and Ahmad al-Asnaj were, in many ways, very different from al-'Abbadi and al-Bayhani. The latter were 'ulama' schooled exclusively in the world of the religious sciences, while the former were educated primarily in secular

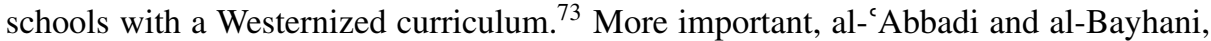
though from scholarly families and well traveled, were from rural backgrounds in the interior of Yemen; they were not of Aden. Luqman and al-Asnaj were both natives of Aden whose fathers had risen from relatively humble origins to positions of prominence. These differences are probably connected to the fact that we see a concerted effort in their writings to reconcile the needs of reform with local ritual, custom, and belief.

Ahmad Muhammad al-Asnaj (d. 1972), as we have noted, was a person of growing importance in the early 1930s. A founding member of Nadi al-Islah, he was also a confidante of the sultan of Mukalla (a British dependency in the Wadi Hadramaut) and a growing intellectual presence. While much of his education was secular, he had studied the religious sciences under the tutelage of Shaykh al-'Abbadi in the early 1930s. AlAsnaj's professional career is difficult to piece together. He appears to have earned his living first as a petition writer and then as a teacher in local secondary schools (as well as dabbling in some business ventures), but he was most notable as an essayist and local lecturer. ${ }^{74}$ Muhammad 'Ali Luqman (1896-1966) was also a principal force behind Nadi al-Islah. In the mid-1930s, his activism took a slightly different turn from the purely religious concerns of some in the club. After working for a period with Antonin Besse Company, one of the wealthiest trading houses in Aden, he attended law school in Bombay in 1936, becoming Aden's first native-born lawyer. In 1940 he founded Fatat al-Jazira, the first in a series of newspapers that by the 1950s had culminated in a virtual media empire, which he used to push a variety of social agendas. ${ }^{75}$

In 1934 al-Asnaj published a collection of essays under the title Nasib 'Adan min alHaraka al-Fikriyya al-Haditha (Aden's Part in the Modern Intellectual Movement). ${ }^{76} \mathrm{~A}$ few years later, in 1939, Luqman published a novella titled Sa id, the story of Sa'id ibn Salman and his family as they navigate the struggles of life in colonial Aden; it is widely regarded as the first work of modern fiction written by an Adeni. ${ }^{77}$ Like al- ${ }^{c}$ Abbadi, al-Asnaj and Luqman were concerned with the spiritual health of their community. Their anxieties, however, were couched in far broader social terms. In Nasib 'Adan al-Asnaj critiqued the dangers facing Adeni Muslims and the perceived moral turpitude and social malaise, which he felt was most evident among "the youth." "Dazzled by charm" and ignorant, he wrote, they had fallen into "a chasm of depravity . . . like a fly into squalor." ${ }^{\prime 7}$ In his introduction to $S a^{c} i d$, Luqman laid the blame for society's decline, at least in part, on conspicuous consumption:

Aden was prosperous at the beginning of this century; its Arab inhabitants were tied to the register of commerce and they owned tens of thousands of transport animals, cattle, goats and sheep. They did not spend their profits on their leisure and luxuries, [instead] saving immense wealth for their sons ... Today ... the people of Aden have reached a state that is closer to conditions of poverty; most of the wealthy exhaust their riches on luxuries which leaches [their wealth] abroad [i.e., to foreigners]: costly automobiles and gasoline, electricity and ice, the cinema, mila, ${ }^{79}$ and clothes—none [of which] lasts but a few days before it becomes an old fashion—as well as liquor and drugs. 
For al-Asnaj and Luqman the corruption of society was due in part to what they viewed as the temptations of modern society, especially alcohol, drugs, and the unbridled desire for consumer luxuries. In addition, both argued that a large part of society's problems lie in the lack of modern education for both men and women and their failure to embrace the modern world more responsibly. ${ }^{80}$ But, like al- ${ }^{c}$ Abbadi, they also believed that the corruption of society was linked to growing impiety. As al-Asnaj noted:

... the enemy struts among us morning and night and corrupts the morality of the youth and guides them towards the path of evil and turpitude and with it they are happy and under its power; he who is licentious is damned by God. And if the youth prefer licentiousness they are guided by error and leave the path of Islam and reject the teachings of the Qur'an, and they reach a state of committing every forbidden thing and neglecting everything that is required of a person-every religious obligation and every obligation to the nation ... ${ }^{81}$

It was here that al-Asnaj and Luqman departed from what is often considered mainstream Salafi teachings. Al-'Abbadi, like many Salafi preachers of his day, argued that the root causes of society's decline were erroneous doctrinal practices such as $d h i k r$ and saint veneration, which ultimately led to moral depravity. Like most Salafis, al-'Abbadi and al-Bayhani believed the faith needed to be cleansed of these and other innovations. Al-Asnaj and Luqman held a somewhat different perspective. While doctrinal backsliding was certainly a problem, ignorance, superstition, and personal weakness in the face of temptation were the real causes of social decay. They categorically condemned superstition as something that held back society. Al-Asnaj inveighed against numerous "disapproved-of customs," which were promoted by the ignorant. These included the beating of drums and chanting to ward off solar and lunar eclipses, the sacrificing of a sheep on the doorstep of a new bride to protect her against jinn, and the consultation of astrologers for important life events such as business transactions and marriage contracts. ${ }^{82}$ Luqman wrote of the "silly practices" of women, "like $z \bar{a} r$, charms and amulets, votive offerings, pilgrimages and tomb visitations . . to seek remedies for barrenness or hysteria or even from maladies like diabetes and tuberculosis at the tombs of the saints!!" 83

While denouncing certain local customs as harmful superstitions, however, Luqman and al-Asnaj endorsed others as pious acts. There was certainly such a thing as improper tomb visitation, as Luqman notes previously, and appealing to the saints for remedies to physical ailments, for instance, fell into the realm of superstition. Visiting the saints, however, could be a pious act if approached with the right attitude. The saints, in these authors' estimation, could serve as valuable moral exemplars, and their descendants could act as meaningful spiritual guides. In Nasib 'Adan al-Asnaj devoted a brief, though important, essay to the subject of "ziyārat al-awliyä." "Among the benefits of the neighborhoods of Aden," he writes, "is that they each have a saint's festival which is much like an annual exhibition known in Egypt as a mawlid and in Aden as a ziyāra." 84 In its ideal form, he noted, one should go to "the place of domes [i.e., the tomb of the deceased] on the day of ziyāra with the intention of visiting the tomb of the pious saint and invoking God as it is said in the sunna." There "one recalls the good works of the saint during his life, which serves as an uplifting lesson, or we enter the mosque next to the grave and pray to God as a supplication and read something aloud from the Qur'an." 85 
Luqman's fictional hero Sa id, in fact, undertakes a pilgrimage precisely for this kind of spiritual edification.

Sa'id visited the garden of Hasan 'Ali then [went] to the ziyāra at the tomb of Sayyid Hashim al-Bahr, calling upon him for beneficence and favor. The followers of the saint saw him and asked him to drink coffee [with them]. After that, Sa id and the followers went to [visit] the Sharifa 'Aliya, sister of Sayyid Hashim, who had known him since his fingernails were soft [i.e., since he was an infant] ... she was a pure pearl ... And $\mathrm{Sa}^{\mathrm{c}} \mathrm{id}$ was in awe of this pious waliya [lit. friend of God] ... She gave Sa ${ }^{c}$ id advice [regarding his travels], and he took her hand and asked from her [a blessing]. ${ }^{86}$

Ziyārāt, in these authors' estimation, served a valuable spiritual function. The act of visiting the tomb offered the believer an opportunity to reflect on the personal meaning of his or her faith. At the same time, those associated with the deceased saint (e.g., Luqman's Sharifa 'Aliya) could provide meaningful spiritual guidance. As al-Asnaj noted, the tombs and the saints were a "benefit" to society.

Local pilgrimages as practiced, however, were not without their problems. In addition to the problem of superstition already mentioned, the festivals associated with ziyārāt tended to encourage the kind of conspicuous consumption that, in Luqman and al-Asnaj's view, so often led to depravity. At each ziyāra, "people seek to outdo one another, men and women, young and old, all of them in new clothes as if for a Ramadan festival." ${ }^{\prime 7}$ More troubling than people wasting their hard-earned money was the utter wantonness of the surrounding festival. To attend a ziyära was to witness "the decline of morality" and to be forced to observe "ghastly things, such as those who occupy themselves with flirtatiousness and seduction, drunks, and debaucherous libertines . . . and all kinds of gambling that even draw in children . . . as well as dancing with the mixing of men and women [and with drums] beating with a wantonness that wounds Islam." ${ }^{88}$

Both al-Asnaj and Luqman were quick to insist that they did not oppose ziyārāt or the veneration of the saints. Al-Asnaj stated that when his opponents "ask if I love the saints [I say] 'Who does not love the pious worshippers of God?' and verily I believe of necessity in their honor." ${ }^{89}$ Similarly, Luqman noted that "some of those among the rash are of the opinion that I hold extreme views regarding such silliness, but those with even the least reason or awareness know that I am among the lovers of the saints ... but I do not like placing others next to God." "90 Yet the wanton activities associated with local festivals made all who attended complicit in one way or another. While no one was forced to take part in such goings on, Luqman related in Sa id, most "foreswear the virtuous and follow carnal desires." 91 But even those who avoided these activities carried some amount of guilt. "There are a few people," al-Asnaj wrote, "who are satisfied with visiting the tomb, but can any among them be satisfied with this practice? No, by God! They are responsible to the Imam of God for what they know ..." How could one sit by while such things went on? "Would the wāli approve?" al-Asnaj asked. ${ }^{92}$

CONCLUSIONS: REFORMIST DISCOURSE, EMPIRE, AND

LOCAL CONTEXT

The impact of any of these writings on the public at large is difficult to gauge. Nadi al-Islah continued to exist at least through the late 1930s, and both al-Asnaj and Luqman 
remained active and important members. ${ }^{93}$ Neither saw their willingness to make accommodations with local practice as compromising their broader commitment to reformist ideals. ${ }^{94}$ In 1938, as president of Nadi al-Islah, al-Asnaj arranged scholarships for alBayhani and others to study at al-Azhar in Cairo. ${ }^{95}$ In 1939, the same year he published $\mathrm{Sa}$ id, Luqman delivered a series of lectures to the club entitled "The Beauties of Islam." As in the novella, these talks denounced "superstition" while explicitly praising the thought of the reformers of the age, such as al-Afghani, Abduh, and Rida. ${ }^{96}$ In addition, all three Adeni reformers continued to play prominent roles in the settlement's intellectual life. ${ }^{97}$ Luqman, as already noted, established a number of newspapers, most notably, Fatat al-Jazira, which began publication in 1940. Al-Asnaj continued to write essays and give weekly lectures to the club's members, while al-Bayhani wrote and published numerous Salafi tracts following his return from Cairo. ${ }^{98}$ In contrast, $d h i k r$ did not cease within the city nor did the various ziyārāt become less popular. Gambling, dancing, and all the other activities associated with the festivals continued, though the British authorities required them to move to the outer edges of the celebrations.

The story presented here allows us to add nuance to recent scholarship concerning Islamic reform and its trajectory within local contexts outside the highest levels of discourse. Salafi reform in Aden, as we have seen, did not sweep all before it once it gained a local foothold. Instead, significant—one could even say successful—resistance by local individuals forced Salafi proponents to proceed far more carefully in the propagation of their teachings. Preachers such as al-'Abbadi and al-Bayhani (as well as their patrons, al-Hindi and Sayyid 'Ali Isma'il) quickly found that heavy-handed tactics got them nowhere and that a more subtle approach, as evidenced in the Hidayat al-Murid, was necessary.

Though softening their approach, al-'Abbadi and al-Bayhani maintained what are often viewed as mainstream Salafi teachings, namely, that the problems of Adeni society were a direct result of various doctrinal shortcomings (e.g., dhikr and saint veneration) that must be addressed if society were to prosper. Other reformist voices, notably those native to Aden, took a somewhat different tack. Luqman and al-Asnaj, both Aden natives, tended to eschew such issues of doctrine and focused instead on the more readily apparent moral failings of society. The problems in society had less to do with issues of doctrinal interpretation than with individual moral conduct and the avoidance of reprehensible activities such as gambling and drinking, as well as superstitions such as $z \bar{a} r$ and magical charms, all of which distracted one from a pious life. They saw dhikr and ziyārāt , in and of themselves, as not only blameless but also laudable. For Luqman and al-Asnaj, local beliefs and practices such as these could play an important role in the reformist agenda.

As noted earlier, Samira Haj has persuasively argued that while Salafism looked to an ideal of the Islamic past and tradition for inspiration, tradition is not about the simple recording of earlier beliefs and practices for posterity. Rather it serves to aid each generation in confronting the problems of its own particular age. ${ }^{99}$ This is a process that results in almost constant reinvention. For Haj, Salafism is a fundamental reimagining of early Islamic tradition as a path for dealing with the colonial present. Her own work on Muhammad Abduh is based on an engagement with the highest levels of reformist discourse. A similar process can be discerned at the local level. While al-Asnaj and Luqman were certainly enamored of Salafi thought, both recognized (consciously or not) elements that were not compatible with local institutions and beliefs-that is, 
traditions. This incompatibility, in their view, would ultimately result in the failure of the ideology to win broad acceptance.

As a result, these activists tweaked the message of reform not only in order to make it more palatable but also to address what most of their fellow Adenis viewed as the true crux of the problem. Instead of emphasizing fairly obscure issues of doctrine that hardly anyone understood, al-Asnaj and Luqman pointed to issues few Adenis would argue were not severe social problems (prostitution, drinking, idleness, and gambling). Rather than vilifying local icons and customs, the two natives of Aden made them part of the solution as examples of pious behavior and sources of moral guidance. The lives of the saints and the festivals surrounding them provided believers with moral focus and the saints' descendants were fonts of advice and direction. While reform within society was essential, both authors argued that local tradition and custom had a role in making that a reality.

In co-opting ziyārāt and the cult of the saints into their own message of reform, it seems unlikely that al-Asnaj and Luqman were acting purely opportunistically (manipulating images and beliefs simply in order to influence the public). It seems far more likely that in their effort to address society's problems both sought to draw on their own stockpile of local traditions, which, along with the teachings of Salafism, offered solutions to the moral quagmire in which they found themselves. In short, they sought to transform Salafi reform, melding the local with the global in order to remedy the maladies of their society.

\section{NOTES}

Author's note: This paper is part of a larger project on the social history of colonial Aden. I thank the many individuals who have assisted me in uncovering the frequently obscure history of Aden, including the curators of the Hamballa Institute in Aden, Maher Luqman in Jiddah, John Shipman and Leila Ingrams in London, and Flagg Miller at the University of California, Davis, as well as the staff of the India Office Library Reading Room at the British Library, who were critical to the locating of sources used in this paper. I am also deeply indebted to various friends and colleagues whose input was vital to the paper's development, including Anne Bang, Carl Ernst, Amal Ghazal, Nile Green, Kai Kresse, Michael Laffan, Marc Matera, Ebrahim Moosa, Omid Safi, Edward Simpson, Abudlkader Tayob, and John Willis, whose insightful suggestions have made this a better piece. I also thank Ulrike Freitag and the Zentrum Moderner Orient in Berlin for a two-month fellowship in June and July 2010, which provided the space for completion of the final draft. And last but not least, I thank the four challenging IJMES reviewers as well as the editorial skills of Beth Baron and Sara Pursley, whose comments and scrupulous revisions have been invaluable.

${ }^{1}$ R/20/A/3465, no. 921, Zikr in Zakariya's mosque, Ltr to Resident, 29 February 1929, India Office Library (hereafter IOL). The vast majority of letters and petitions to the state found in the Aden Residency files located in the India Office Library are in the original Arabic.

${ }^{2}$ Those subscribing to Salafi ideology, however, hardly held a monopoly on this term. Numerous writers of various ideological stripes used it during the 19th century, frequently applying a much broader definition of who was included in the "pious ancestors." For example, the term frequently included the eponymous founders of the four Sunni law schools-Malik b. Anas, Abu Hanifa, Ahmad ibn Hanbal, and Muhammad al-Shafi $i$ - as well as other luminaries such as al-Ghazzali.

${ }^{3}$ Amal N. Ghazal, "The Other Frontiers of Arab Nationalism: Ibadis, Berbers, and the Arabist-Salafi Press in the Interwar Period," International Journal of Middle East Studies 42 (2010): 105-22.

${ }^{4}$ Ibid.; David Commins, Islamic Reform: Politics and Social Change in Late Ottoman Syria (Oxford: Oxford University Press, 1990), 4. The roots of modern Islamic scripturalism can be dated even earlier, to 18th-century thinkers such as the South Asian scholars Sirhindi and Shah Wali Allahal-Dihlawi as well as the Najdi 'ālim Muhammad ibn 'Abd al-Wahhab. An in-depth discussion of the place of these individuals in the 
history of reformist discourse is beyond the scope of this paper. On Sirhindi and Shah Wali Allah see Barbara Metcalf, Islamic Revival in British India: Deoband, 1860-1900 (Oxford: Oxford University Press, 1982) and Marcia Hermansen, trans. and ed., The Conclusive Argument for God, Shah Wali Allah of Delhi's Hujjal Allah al-Baligha (Leiden: E. J. Brill, 1995). On Ibn 'Abd al-Wahhab see David Commins, The Wahhabi Mission and Saudi Arabia (London: I. B. Taurus, 2009).

${ }^{5}$ Albert Hourani, Arabic Thought in the Liberal Age (Cambridge: Cambridge University Press, 1962).

${ }^{6}$ Ghazal, "The Other Frontiers," 106.

${ }^{7}$ Oliver Scharbrodt, "The Salafiyya and Sufism: Muhammad Abduh and his Risālat al-Wāridāt (Treatise on Mystical Inspirations)," Bulletin of SOAS 70 (2007): 89-115.

${ }^{8}$ David Commins, Islamic Reform; Itzchak Weismann, "Between Șūfī Reformism and Modernist Rationalism-A Reappraisal of the Origins of the Salafiyya from the Damascene Angle," Die Welt des Islams 41 (2001): 206-37.

${ }^{9}$ Itzchak Weismann, "Between Sūfī Reformism and Modernist Rationalism,” 206.

${ }^{10}$ Samira Haj, Reconfiguring Islamic Tradition: Reform, Rationality and Modernity (Stanford, Calif.: Stanford University Press, 2009), 6-7. Haj's argument is a good deal more nuanced and complex, but the limits of space do not permit a more detailed overview of this important work.

${ }^{11}$ This view has recently been strengthened by Henri Lauzière, "The Construction of Salafiyya: Reconsidering Salafism from the Perspective of Conceptual History," International Journal of Middle East Studies 42 (2010): 369-89.

${ }^{12}$ Other notable contributions to this growing body of literature include Michael Francis Laffan, Islamic Nationalism and Colonial Indonesia: The Umma Below the Winds (London: Routledge-Curzon, 2003); Ghazal, "The Other Frontiers"; and Francis Robinson, "Islamic Reform and Modernities in South Asia," Modern Asian Studies 42 (2008): 259-81.

${ }^{13}$ Two notable exceptions are Justin Jones' recent article, "The Local Experiences of Reformist Islam in a 'Muslim' Town in Colonial India: The Case of Amroha," Modern Asian Studies 43 (2009): 871-908; and Nile Green, Bombay Islam: The Religious Economy of the West Indian Ocean, 1840-1915 (Cambridge: Cambridge University Press, 2011).

${ }^{14}$ This notion is acknowledged by Justin Jones in "The Local Experiences of Reformist Islam" but demonstrated with only circumstantial evidence.

${ }^{15}$ In fact, these are likely conservative numbers, as they do not count the garrison (including camp followers), more transient populations such as those of day laborers, merchants, and pilgrims, or those who actively sought not to be counted.

${ }^{16}$ Figures for the 1839,1849 , and 1871 censes can be found in the following IOL files: R/20/E/5; R/20/E/34; R/20/A/400. Figures for the 1931 census are from R. J. Gavin, Aden Under British Rule: 1839-1967 (London: C. Hurst \& Co., 1975), 445.

${ }^{17}$ Alexander Knysh, "The Cult of the Saints and Religious Reformism in Hadhramaut," in Hadhrami Traders, Scholars and Statesmen in the Indian Ocean 1750-1960s, ed. Ulrike Freitag and W. G. ClarenceSmith (Leiden: E. J. Brill, 1997).

${ }^{18}$ In 1839 the ziyāra was held only a month or so after the British occupation with thousands of faithful reportedly attending from the surrounding districts despite the political uncertainty. R/20/E/5, Report Haines to Bombay, 11 July 1839 , IOL.

${ }^{19}$ R/20/A/2664, Fairs, 1911-1936, IOL. While many local ziyārāt were major events attracting thousands of participants and onlookers, others were much smaller affairs organized by particular communities, such as the ziyāra of Shaykh Rihan, a one-day festival organized each year by local fishermen. It is difficult to determine when all of these ziyārāt originated, but many were in evidence by the latter part of the 19th century. The former Assistant Resident Capt. F. M. Hunter listed fourteen such festivals in his An Account of the British Settlement of Aden in Arabia (London: Trübner, 1877), 173-76. The list, however, is not identical with those cited in the Aden Residency file.

${ }^{20}$ For instance, a note dated 24 May 1928 states that the Treasury Office would be closed "on account of the Fair of Syed Hashem al-Baher." R/20/A/2664, IOL.

${ }^{21}$ R/20/A/2664, "Fairs, 1911-1936," IOL. While important, the British official attitude toward popular piety in Aden is beyond the scope of this article. For an informative discussion of British pragmatic tolerance of local forms of spirituality see Nicholas Dirks' discussion of "hookswinging" in 19th-century India, in Castes of Mind: Colonialism and the Making of Modern India (Princeton, N.J.: Princeton University Press, 2001). 
${ }^{22} \mathrm{R} / 20 / \mathrm{A} / 2664$, "Fairs 1911-1936," folios on the Ziyaras of Shaykh Abban and Shaykh Ahmad al-Iraqi, IOL.

${ }^{23} \mathrm{R} / 20 / \mathrm{A} / 2664$, Letter of protest, 7 May1932, IOL, outlining complaints of irreligious activity at local ziyārāt. R/20/A/3471,"Shaykh Othman Fair," IOL.

${ }^{24} \mathrm{R} / 20 / \mathrm{A} / 2906$, “Zar," IOL.

${ }^{25}$ R/20/A/2906, Petition to the First Assistant Resident, 24 December 1923, IOL.

${ }^{26}$ This was hardly the end of the matter, however. Over the next ten years, the chief practitioners deluged the registrar and first assistant resident with petitions begging them to reverse the decision. Time and again, the ban was upheld, and by the mid-1930s the petitions ceased. For a detailed overview of this case see Lidwien Kaptiejns and Jay Spaulding, "Women of the Zar and Middle-Class Sensibilities in Colonial Aden, 1923-1932," in Voice and Power: The Culture of Language in Northeast Africa, Essays in Honor of B. W. Andrzejewski, ed. R. J. Hayward and I. M. Lewis, African Languages and Culture Suppl. 3 (1996): 171-89.

${ }^{27}$ The club is referred to by a variety of names in both British archival records and local Arabic-language publications, sometimes even within the same text; these include the Arab Islamic Reform Club, Arab Reform Club, the Islamic Reform Club, and the Arab Literary Club. For the sake of simplicity I use Nadi al-Islah or Reform Club.

${ }^{28}$ R/20/A/3390, Letter from Muhammad Ali Luqman to Major H. M. Wightwick, Acting Political Resident, Aden, 24 June 1931, IOL.

${ }^{29}$ For more on the backgrounds of these individuals see Scott S. Reese, "The Respectable Citizens of Shaykh Uthman," in Struggling with History, ed. Kai Kresse and Edward Simpson (London: Hurst, 2008).

${ }^{30}$ Luqman also spent time at Aligarh University in the 1920s and would go on to obtain a law degree in Bombay in the mid-1930s. However, his education was not entirely secular. In addition to his Western schooling, while in his teens Luqman studied fiqh and other elements of the religious sciences with Aden scholars, including the pre-World War I qadi of Aden Sayyid Muhammad al-Hazimi. M. A. Lokman and Ahmed Ali al-Hamdani, eds., Men, Matters and Memory (n.p., 2009), 52-54. This recently published work is a compilation of Luqman's serialized autobiography that appeared in his weekly English language newspaper The Aden Chronicle during the early 1960s.

${ }^{31}$ Al-Asnaj's education is unclear, but judging from his own writings he seems to have benefited from a mixture of secular and religious education. For information on Muhammad Sa id al-Asnaj (Ahmad's father) see the petition requesting the banning of gambling and other indecent activities at the ziyāra of Hashim al-Bahr in R/20/A/2664, IOL.

${ }^{32}$ Lokman, "First Literary Club in South Arabia," in Men, Matters and Memories, 136. This piece appeared on 3 August 1961. For a brief discussion of al-Tha'alibi's involvement with transnational Salafism see Ghazal, "The Other Frontiers."

${ }^{33}$ Luqman notes in his autobiography that his first attempt to establish the club in 1924 was something of a false start. While initial interest was strong, after a few years the organization had only twelve dues-paying members. It was not until 1928 that a revived club began to establish itself on the social scene. Lokman, "First Literary Club in South Arabia," 136.

${ }^{34} \mathrm{R} / 20 / \mathrm{A} / 3452$, file no. 891, Haslam to Hickinbotham, 23 March1932, IOL.

${ }^{35} \mathrm{R} / 20 / \mathrm{A} / 3390$, Luqman to Wightwick, 24 June 1931 and Laghton to Luqman, 29 July 1929, IOL.

${ }^{36}$ Al-'Abbadi's education and career are summarized in a number of documents. The most comprehensive is the laudatory biography composed by his student and later Salafi luminary, Muhammad b. Salim b. Husayn al-Bayhani, and included in a collection of al-'Abbadi's poetry, Hidayat al-Murid ila Sabil al-Haqq wa-lTawhid, li-na Zamha al-Ustadh al-Jalil wa-l- 'Alama al-Salafi al-Nabil al-Shaykh Ahmad bin Muhammad bin Awadh al-'Abbadi al-Yamani [Guidance of the Seeker Along the Path of Truth and Doctrine], 2nd ed. (Cairo: al-Matba'a al-Salafiya wa-Maktabatuha, 1969). This volume will be discussed.

${ }^{37} \mathrm{Al}-{ }^{\mathrm{c}}$ Abbadi, Hidayat al-Murid, 1.

${ }^{38}$ Ibid.

${ }^{39} \mathrm{He}$ is also said to have made shorter sojourns in Persia.

${ }^{40} \mathrm{Al}-{ }^{-}$Abbadi, Hidayat al-Murid, 2.

${ }^{41}$ One police intelligence report contends that he arrived in Lahej as late as 1929 and remained there for only eighteen months. R/20/A/3390, Police report on Ahmad bin Ahmad al-Abbadi, 5 June 1931, IOL.

${ }^{42} \mathrm{Al}$-Bayhani asserts that al- ${ }^{\mathrm{C}} \mathrm{Abbadi}$ founded Nadi al-Islah after his arrival, but all other sources contradict this assertion. 


\section{Scott S. Reese}

${ }^{43}$ The shaykh's detractors, such as the former qadi of Shaykh Uthman, Awadth b. 'Abdullah Sharaf, would certainly argue that his presence was responsible for the social tensions of the 1930s; however, there is nothing to suggest that al- 'Abbadi's presence was the sole or even precipitating factor.

${ }^{44}$ Henri Lauzière, "The Construction of Salafiyya."

${ }^{45} \mathrm{Al}$ - Abbadi's unambiguous stance against tomb visitation would certainly place him in this category and was sufficient for his student to refer to him as "the learned Salafi" on the title page of the Hidayat in the late 1930s. At least one recent Yemeni author has referred to him as "one of the earliest Salafis in southern Yemen." See Ahmad ibn Hasan, Qaburiya fi al-Yaman: Nasha'atuha Atharuha Mawqif al- 'Ulama’ minha (Sana'a, Yemen: Markaz al-Kalima al-Tayyiba li-1-Buhuth wa-1-Dirasat al-'Ilmiyya, 2003), 232. Similarly, upon his return to Aden, al-Bayhani embarked on a lengthy reform-focused writing career, including, most notably, a hadith commentary, Islah al-Mujtama (Medina, Saudi Arabia: al-Maktaba al-'Ilmiyya, 1975). This work is still in print, as is al-Sarm al-Qirini, a response to critics of al-'Abbadi's poems. The latter, unfortunately, exists only in manuscript form and has never been published. Ahmad Hasan references it in Qaburiya as a response to the "tomb worshippers" (p. 235).

${ }^{46}$ Luqman was exposed to a wide range of reformist thought during his youth in both India and the Arab world. He contributed pieces to newspapers in India that included the Bombay Sentinel, Bombay Mainland, and Bombay Chronicle as well as the Cairo newspapers al-Jihad,al-Balagh, and al-Shura. Despite receiving his legal education in Bombay and working for a short time at Aligarh University it was the Arab side of reform toward which Luqman was drawn. In his autobiography he describes a rather uncomfortable time at Aligarh largely as a result of his contempt for the Caliphate movement. He also maintained a lifelong friendship with al-Tha'alibi, and in a series of lectures delivered to Nadi al-Islah in 1939 he praised al-Afghani, Abduh, and Rida as "defenders" of the "fundamental principles and tenets of the Qur'an." Lokman, Men Matters and Memories, 153, 211-12, 220. Even as his own path became self-reflexively "Pan-Arabist," Luqman published an editorial in Fatat al-Jazira on 26 November 1944 commemorating al-Tha'alibi's death and describing him as a "pillar of Islam and [an] Arab hero," along with al-Afghani, Abduh, and Rida. Many of Luqman's Fatat editorials are collected in al-Mujahid Muhammad 'Ali Luqman, Fatat al-Jazira, Ifttahiya wa-Maqalat min 'Am 1940-1950, ed. Ahmad 'Ali al-Hamdani (n.p., 2006)

${ }^{47}$ Such a mix of intellectual agendas coming together around the notion of a Muslim moral community was hardly unusual during this period. See Michael Gasper, The Power of Representation: Publics, Peasants and Islam in Egypt (Stanford, Calif.: Stanford University Press, 2009), esp. 48-51, 119-23.

${ }^{48} \mathrm{R} / 20 / \mathrm{A} / 3390$, IOL.

${ }^{49}$ Ibid. A copy of this sermon in the original Arabic was obtained by a police informant present during the Friday prayers. It came to the attention of British authorities because of the inclusion of remarks that denounced atrocities committed by Italian authorities in Libya during the preceding months. The sermon is attributed by association to Muhammad 'Ali Luqman, but while he gave a number of sermons it is not clear that he delivered this particular one.

${ }^{50}$ R/20/A/2664, "Fairs 1911-1936," Petition to Wightwick, First Assistant Resident, 7 May 1931.

${ }^{51} \mathrm{R} / 20 / \mathrm{A} / 3465$, file no. 921, IOL.

${ }^{52} \mathrm{R} / 20 / \mathrm{A} / 2664$, Petition to Resident, 6 May 1931, IOL. It may be noticed that this petition predates Sayyid 'Ali's petition by one day. In order to gain sufficient signatures such petitions to the authorities generally circulated through various neighborhoods for several days before being sent forward to the Residency. As a result it is not surprising that those opposed to it had time to put together their own counter-petition and submit it as quickly as their opponents. Dates were frequently assigned to documents as they came in to the Residency Clerk's office, and in this case it would appear that the pro-ziyāra petition simply passed Sayyid 'Ali's anti-ziyāra one in the bureaucratic queue.

${ }^{53}$ R/20/A/2664, Ltr to the Resident from Ahmadi Sufis, 3 March 1932, IOL; Ltr. to Inspector of Police from Zakariya Muhammad, 25 February 1932; Ltr. to the Magistrate from Zakariya Muhammad, 10 March 1932, IOL.

54"Verily the Almighty and His Angels shower blessings upon His Prophet. Oh Believers! Send blessings upon him and salute him with a worthy salutation." Sura 33:56, The Confederates. Special thanks to Omid Safi, Ebrahim Moosa, and Omer Mozzafer for their help in tracking down this reference.

${ }^{55} \mathrm{R} / 20 / \mathrm{A} / 3465$, file 921 , Note to the Commandant of Police, 11 January1933, IOL

${ }^{56}$ See R/20/A/3465, file 921, and R/20/A/3390, IOL.

${ }^{57}$ For their own part, the British authorities attempted to affect a position of stunning impartiality in these events. They tended to view the matter as largely one of petty squabbles between various elite factions, and 
their own overriding concern seemed to be the maintenance of authority. Thus, in addition to threats they frequently sought compromises between the conflicting parties. They also began to take what were viewed as prudent security precautions, for instance, deploying extra police as well as an armored car or two at the Sayyid Hashim ziyāra in order to deter disruptions. R/20/A/2664, "Fairs 1911-1936," IOL.

${ }^{58}$ Guidance of the Seeker Along the Path of Truth and Doctrine.

${ }^{59} \mathrm{Al}-{ }^{\mathrm{C}}$ Abbadi, Hidayat al-Murid, 5.

${ }^{60}$ Ibid., 64.

${ }^{61}$ Ibid. A second edition was published by the same press in 1969, to which another work, Bi-Hujat alQulub bi-Tawhid 'Alam al-Ghayub was attached. Like the Hidayat this was a poetry collection by another noted Salafi shaykh, Qadiri b. Ahmad al-Ahdal, but it was written much later, in 1969. I thank Dr. Alan Godlas for the leads that enabled me to track down the history of this work.

${ }^{62}$ Literally 'adat mustihajna or "disapproved-of customs," a phrase used liberally by Ahmad al-Asnaj but certainly appropriate to the views of al-'Abbadi and al-Bayhani.

${ }^{63}$ Al-'Abbadi, "On the Tariqa and the Sharic a," in Hidayat al-Murid, 32-34.

${ }^{64} \mathrm{Al}-{ }^{\mathrm{C}}$ Abbadi, "On Idolatry and Its Types," in Hidayat al-Murid, 24-25.

${ }^{65}$ Al-'Abbadi, "The Verdict on Tomb Visitation," in Hidayat al-Murid, 47-56.

${ }^{66}$ Literally, "Oh Shaykh So-and-So."

${ }^{67}$ Al- 'Abbadi, Hidayat al-Murid, 25, n. 1. The footnote was composed by al-Bayhani, who edited the entire work. Emphasis mine.

${ }^{68}$ Ibid., 14, n. 1.

${ }^{69}$ Ibid., 7-8.

${ }^{70}$ Ibid., 13-14.

${ }^{71}$ Ibid., 24.

${ }^{72}$ Ibid, 24, n. 3.

${ }^{73} \mathrm{Al}-\mathrm{Bayhani}$ was educated first in the Hadramaut and then came to Aden specifically to study under al-'Abbadi. In the late mid-1930s he attended the famed al-Azhar in Cairo under a scholarship provided by Nadi al-Islah. Hasan, Qaburiya, 234.

${ }^{74}$ Ahmad al-Asnaj lived to see independence in 1967 but ran afoul of the ruling communist authorities and died shortly after his release from prison in 1972.

${ }^{75}$ Fatat was followed by al-Qalam al- 'Adani, a weekly literary paper, and The Aden Chronicle, a weekly English-language paper; both were founded around 1950. All of these were published until the end of colonial rule in 1967.

${ }^{76} \mathrm{Al}$-Asnaj published another set of essays, Irij 'Adan in 1959. These were lectures originally delivered to various local groups between the mid-1930s and late 1950s.

${ }^{77}$ Many Adenis today consider Muhammad 'Ali Luqman Aden's premier intellectual, and thus many of his essays, short stories, and newspaper editorials have recently been published in a number of collections. The novella Sa'id can be found in al-Mujahid Muhammad 'Ali Luqman al-Muhami (6 November 1898-22 March 1966): Ra'id al-Nahda al-Fikri wa-l-Adabiyya al-Haditha fi al-Yaman, ed. Ahmad Ali al-Hamdani (n.p., 2005).

${ }^{78}$ Al-Asnaj, Nasib 'Adan min al-Haraka al-Fikriyya al-Hadithiyya: Khatarat wa-Muhadarat li-l-Adib al'Adani al-Ma'aruf al-Ustadh Ahmad Muhmmad al-Asnaj, Mudir Nadi al-Islah al-'Arabi al-Islami fi Adan, (Aden: n.p., 1934), 4.

${ }^{79}$ This appears to be a very curious use of the Urdu word for "festival." Thanks to John Willis for this clarification.

${ }^{80}$ Luqman,"Introduction” to Sa id, in al-Mujahid Muhammad 'Ali Luqman, 397-98.

${ }^{81}$ Al-Asnaj, Nasib 'Adan, 5.

${ }^{82}$ Ibid., 33, 36, and 40.

${ }^{83}$ Luqman, "Sa'id," in al-Mujahid Muhammad 'Ali Luqman, 398.

${ }^{84}$ Al-Asnaj, Nasib 'Adan, 54.

${ }^{85}$ Ibid.

${ }^{86}$ Luqman, "Sacid," 423-24.

${ }^{87}$ Al-Asnaj, Nasib 'Adan, 54.

${ }^{88}$ Ibid.

${ }^{89}$ Ibid., 56.

${ }^{90}$ Luqman, "Sa id," 424. 


\section{Scott S. Reese}

${ }^{91}$ Ibid.

${ }^{92}$ Al-Asnaj, Nasib 'Adan, 55.

${ }^{93}$ R/20/A/3452, no. 891, report no. C/8, Police Inspector, Crater, 3 October 1938, IOL. This report lists Ahmad al-Asnaj as the president of the club with Muhammad 'Ali Luqman as its vice president. It also notes that at the time of writing the club had about 150 dues-paying members.

${ }^{94} \mathrm{Al}$-Asnaj's and Luqman's views were in fact very similar to the effendiyya reformers of the Egyptian middle class during the same period. The difference between them, however, was that the effendiya sought the abolition of saints' festivals, while the two Adenis argued that they could be reformed. See Samuli Schielke, "Hegemonic Encounters: Criticism of Saints-day Festivals and the Formation of Modern Islam in Late 19th and Early 20th-century Egypt," Die Welt des Islams 47 (2007): 319-55.

${ }^{95} \mathrm{Al}-$ Bayhani traveled to Egypt in 1938 and was resident there for three years, according to his biography in the Qaburiya. While in Cairo he obtained two degrees from al-Azhar and returned to Aden, where he established an institute for higher learning. Hasan, Qaburiya, 234. See also R/20/B/1531, c. 45/1, Status of the Arab Reform Club in Aden, 1938, IOL.

${ }^{96}$ R/20/A/3452, no. 891, report no. C/8, 3 October 1938, IOL; Lokman, Men, Matters, Memories, 220-21.

${ }^{97} \mathrm{Al}-{ }^{\mathrm{c}}$ Abbadi disappeared from the written record after the early 1930s. It is possible that he left the settlement, passed away, or simply retired from preaching to manage the numerous properties he had purchased since arriving in Aden.

${ }^{98}$ Hasan, Qaburiya, 232-35.

${ }^{99}$ Haj, Reconfiguring Islamic Tradition, 6-7. 